\title{
Selection of the most suitable crustacean exoskeleton waste from fish processing industry to isolate chitosan
}

\author{
R.G. Sanuja ${ }^{1}$, Nishantha K. Kalutharage*2 ${ }^{*}$ d P. Ruchira T. Cumaranatunga ${ }^{1}$ \\ ${ }^{1}$ Department of Fisheries and Aquaculture, Faculty of Fisheries and Marine Sciences \& Technology, \\ University of Ruhuna, Matara, Sri Lanka \\ ${ }^{2}$ Department of Chemistry, Faculty of Science, University of Ruhuna, Matara, Sri Lanka
}

*Corresponding Author (knishantha@chem.ruh.ac.lk)

\begin{abstract}
Shell waste produced by the sea food industry is one of the most significant problems contributing for environmental and health hazards. The most frequent method employed for disposal of these waste is burning which is environmentally costly due to low burning capacity of shells. In such a scenario, conversion of shrimp shell waste to chitosan, a commercially valuable product with a myriad of uses, could serve as an effective mode of shell remediation. Chitosan was obtained from shellfish waste by deproteination, demineralization, discoloration and deacetylation processes. It was characterized using Fourier Transformed Infra-Red (FT-IR) spectroscopy. The physico-chemical parameters such as moisture content, ash content, solubility, N-content, water binding capacity (WBC), fat binding capacity (FBC) and degree of deacetylation (DD) were analysed to compare the extracted six chitosan samples from Penaeus monodon, Portunus pelagicus, Portunus sanguinolentus, Scylla serrata, Panulirus homarus and Panulirus versicolor. The ranges for percentage yield, moisture content, ash content, N-content, percentage solubility, and WBC were $14.53 \pm 0.47 \%-34.13 \pm 3.72 \%, 3.16 \pm 1.77 \%-7.52 \pm 1.11 \%$, $0.65 \pm 0.23 \%-53.52 \pm 5.65 \%, 2.02 \pm 0.03 \%-6.16 \pm 0.10 \%, 15.28 \pm 0.62 \%-47.91 \pm 5.15 \%$, and $262.94 \pm 20.88 \%-$ $600.61 \pm 58.11 \%$ respectively. FBC varied approximately from $250 \%$ to $650 \%$ in coconut oil, sunflower oil and soybean oil. Among the six chitosan samples, P. monodon was the most suitable crustacean exoskeleton waste from fish processing industry to isolate chitosan due to the fact that in the processing of shrimps for human consumption, 40 - 50\% of the total mass is discarded as waste and high quality of chitosan extracted. Therefore, there is a high possibility of extracting good quality chitosan using exoskeleton waste of Penaeus monodon.
\end{abstract}

Keywords: Chitosan, shellfish waste, Penaeus monodon, deproteination, demineralisation, decolourization

\section{INTRODUCTION}

Chitosan is a polyaminosaccharide synthesized from the deacetylation of chitin, a polysaccharide consisting predominantly of unbranched chains of $\beta-(1 \rightarrow 4)-2-$ acetoamido-2-deoxy-D-glucose. Chitin is the second most abundant polymer in nature after cellulose (Wan Ngah et al. 2010; Wang et al. 2010; Thibaut et al 2016). Chitin occurs in nature as ordered crystalline microfibrils forming structural components in the exoskeleton of arthropods or in the cell walls of fungi and yeast.

Sea food, a delicacy for many are seen in market in a wide variety of products. Sea food industries process and package the harvested products. During the processing, only the meat is taken, while the head and shells of shell fish are discarded as waste. This results in generation of large amount of shell waste globally.

Shell fish industry which is prominent in all costal countries generates large amount of waste. Even though the waste is biodegradable, the dumping of large quantities makes degradation process slow resulting in accumulation of waste over time which is a major environmental concern. A quick and effective solution to this is recycling of shell wastes and extraction of commercially viable substances such as chitin that can further be deacetylated to form chitosan which has a wide range of uses (Ravi Kumar 2000).

Chitosan is a white, hard, inelastic nitrogenous polysaccharide (Badawy and Rabea 2011). It has a variety of applications due to its high biodegradability, non-toxicity and antimicrobial properties. It is used in biomedical industries, agriculture, genetic engineering, 


\section{R.G. Sanuja et al.}

food industry, environmental pollution control, water treatment, paper manufacture, photography etc. (Li et al. 1992; Cheba 2011; Krishnavoni and Ragunathan 2015).

Chitosan is easily obtained from crab especially Cancer magister, shrimp particularly Pandalus borealis, lobster and crawfish shells (Knorr 1991). Traditional isolation of chitin from crustacean shell waste consists of three basic steps: demineralization $\left(\mathrm{CaCO}_{3}\right.$ and $\mathrm{Ca}_{3}\left(\mathrm{PO}_{4}\right)_{2}$ separation), deproteinization (protein separation), and decolorization (removal of pigments) (No et al. 1989). The subsequent conversion of chitin to chitosan (deacetylation) is generally achieved by treatment with conc. $\mathrm{NaOH}$ solution $(40-50 \%)$ at $100^{\circ} \mathrm{C}$ or higher temperature to remove some or all of acetyl group from the chitin (No and Meyers 1995).

Earlier studies by several authors (Cho et al. 1998; No et al. 2000; Trung et al. 2006) have demonstrated that the physicochemical characteristics of chitosan affect its functional properties, which also differ according to crustacean species and preparation methods. Several procedures have been developed and proposed by many researchers over the years for preparation of chitosan from different crustacean shell wastes (Islam et al. 2011). Some of these formed the basis of chemical processes for industrial production of chitosan.

Synthesization and characterization of chitosan derived from shrimp waste of Penaeus monodon has already been studies in Sri Lanka (Sewvandi and Adikary 2012). Present study aims to determine the most suitable crustacean shell type, which can be used to isolate high quality chitosan, out of processing waste of six crustaceans species namely Penaeus monodon, Portunus pelagicus, Portunus sanguinolentus, Scylla serrata, Panulirus homarus and Panulirus versicolor in Sri Lanka. This study may be useful for establishing small scale industries for chitosan production using discarded crustacean shells from seafood processing factories thus emphasizing that they are not a waste, but a source of a raw material for production of highly demanded biopolymer chitosan which has multiple uses in various important industries.

\section{MATERIALS AND METHODS}

Exoskeletons of $P$. monodon and $P$. pelagicus were collected from a large scale shrimp processing factory in Dankotuwa, Sri Lanka. Exoskeletons of S. serrata, $P$. homarus and $P$. versicolor were obtained from two small scale local seafood restaurants in Weligama and Hikkaduwa, Sri Lanka. Exoskeletons of $P$. sanguinolentus were collected by purchasing one $\mathrm{kg}$ of $P$. sanguinolentus from the fish market in Dondra, Sri Lanka.

All crustacean exoskeletons were scraped to remove tissues, washed and sun dried for three consecutive days. To obtain a uniform size product, the dried crustacean shells were ground into fine particles through a centrifugal grinding mill (DM 842-I, Sumeet Research \& Holdings Limited, India) and were sieved through a $400 \mu \mathrm{m}$ sieve. Dried, ground and $\leq 400 \mu \mathrm{m}$ particle sized raw crustacean shells were placed in opaque bottles and stored at ambient temperature in a dry place until use for a maximum of one month. This storage helps the partial autolysis, which facilitates chemical extraction of chitosan improving its quality (Toan 2009).

Three sub-samples of $50 \mathrm{~g}$ each from dried, ground and $\leq 400 \mu \mathrm{m}$ particle sized raw crustacean shells were used to isolate chitosan. Five steps, i.e., (i) pre-conditioning (PC), (ii) de-mineralization (DM) (iii) de-proteinization (DP) (iv) de-colouration (DC) and (v) de-acetylation (DA) were used in this isolation.

The first step of the common procedure of the chitosan extraction is pre-conditioning, where the skeletal matrix structure is weakened to easily remove soluble protein by washing with water. Preconditioning was done as described by Sewvandi and Adikary (2012). Preconditioned shell samples were sun dried ad were weighed to the nearest $0.00 \mathrm{~g}$ using an electrical balance (Type PJ 3600, Mettler, Switzerland). Preconditioned exoskeleton was demineralized using $1 \%$ $\mathrm{HCl}$ of four times of its quantity. The samples were allowed to soak for $24 \mathrm{~h}$ to remove the minerals, mainly calcium carbonate as described by Trung et al. (2006). De-proteinization of the demineralized shell samples was carried out as described by No and Meyers (1992). De-proteinized crustacean shell sub-samples were decolorized as described by No and Meyers (1992). Decolorized chitin was converted into chitosan using modified process of deacetylation described by Huang et al. (2004). The chitosan obtained was in a creamywhite form (Muzzarelli and Rochetti 1985).

After isolation, percentage yield, degree of deacetylation and physicochemical and functional properties such as moisture content, ash content, solubility, N-content, water binding capacity (WBC) and fat binding capacity (FBC) were determined. The weight of each chitosan samples were taken after deacetylation and the percentage of yield was 


\section{R.G. Sanuja et al.}

calculated using the equation (No and Meyer 1992):

$$
\text { Yield }(\%)=\frac{\text { Weight of Chitosan sample }(\mathrm{g})}{\text { Weight of raw shell sample }(\mathrm{g})} * 100 \%
$$

Moisture content of chitosan samples was determined by gravimetric method as described by AOAC (1995). Percentage moisture content of chitosan samples were calculated according to the following equation:

$$
\text { Moisture }(\%)=\frac{W W(g)-D W(g)}{W W(g)} \times 100 \%
$$

where WW and DW are the wet and dry weights of chitosan respectively.

Ash content of the chitosan samples were performed using standard ashing method (AOAC 1995). About $0.5 \mathrm{~g}-0.6 \mathrm{~g}$ of each chitosan samples were used for the analyses. Percentage ash content of chitosan samples were calculated according to following equation:

$$
\text { Ash } \%=\frac{\text { Weight of residue or ash }(\mathrm{g})}{\text { Weight of initial chitosan sample }(\mathrm{g})} \times 100 \%
$$

$\mathrm{N}$-content was determined by Kjeldhal method (AOAC 1995) using the Kjeldhal Nitrogen Analyzer. About $1.00 \mathrm{~g}$ of chitosan sample was used for the analysis. Percentage of $\mathrm{N}$ was calculated according to the following equation:

$$
\mathrm{N} \%=\frac{\left(\mathrm{V}_{\mathrm{t}}-\mathrm{V}_{\mathrm{b}}\right) \times \mathrm{N} \times 14.007}{\mathrm{~W}(\mathrm{mg})} \times 100 \%
$$

where, $\mathrm{V}_{\mathrm{t}}=$ Volume of $\mathrm{H}_{2} \mathrm{SO}_{4}$ (in $\mathrm{mL}$ ) used for the titration of chitosan samples; $\mathrm{V}_{\mathrm{b}}=$ Volume of $\mathrm{H}_{2} \mathrm{SO}_{4}$ (in $\mathrm{mL}$ ) used for the titration of blank; $\mathrm{N}=$ Normality of $\mathrm{H}_{2} \mathrm{SO}_{4}, \mathrm{~W}=$ Weight of chitosan sample

Solubility of chitosan samples were measured by the method describe by No and Meyers (1992) with modifications. $0.1000 \mathrm{~g}$ of each chitosan samples were placed into previously weighed centrifuge tubes and 10 $\mathrm{ml}$ of $1 \% \mathrm{CH}_{3} \mathrm{COOH}$ was added and left for 30 minutes. The mixture was then centrifuged (Gallenkamp Centrifuge 200) at 10,000 rpm for 10 minutes. The supernatant liquid was decanted. The un-dissolved particles were washed with distilled water $(25 \mathrm{~mL})$ then centrifuged at 10,000 rpm. The supernatant liquid was removed and the undissolved pellets dried at $60^{\circ} \mathrm{C}$ for 24 hours in an electric oven. Finally, the amount of the residues was weighted and the percentage of solubility was determined.

Water Binding Capacity (WBC) and Fat Binding Capacity (FBC) of chitosan were measured using a modified method described by Knorr (1982). About $0.5 \mathrm{~g}$ of each chitosan sample was used in the analyses. For the determination of FBC three types of oils, i.e., coconut oil, soybean oil and sunflower oil were used.

Dried, powdered chitosan samples were mixed thoroughly with $\mathrm{KBr}$ and then pressed in vacuum using pellet preparation gun to make a homogeneous disc with a thickness of $0.5 \mathrm{~mm}$ (Khan et al. 2002). These discs were used for characterization of chitosan using Fourier Transformed Infra-red (FT-IR) spectroscopy instrument (Brucker Alpha-T)

Degree of deacetylation (DD) was determined using FT-IR Spectroscopy and acid-base titration. In FT-IR Spectroscopy chitosan samples prepared in the form of $\mathrm{KBr}$ discs were kept in desiccators for $12 \mathrm{hrs}$ and then placed in sealed plates before scanning. The DD of chitosan was established using a FT-IR spectrophotometer with frequency of $4000-400 \mathrm{~cm}^{-1}$. The DD of the chitosan was calculated using the baseline cited by Khan et al. (2002). The computation equation for the baseline is given below.

$$
\mathrm{DD}=100-\left[\left(\mathrm{A}_{1655} / \mathrm{A}_{3450}\right) \times 100 / 1.33\right]
$$

where $A_{1655}$ and $A_{3450}$ were the absorbance at $1655 \mathrm{~cm}^{-}$ ${ }^{1}$ of the amide-I band as a measure of the $\mathrm{N}$-acetyl group content and $3450 \mathrm{~cm}^{-1}$ of the $-\mathrm{OH}$ band as an internal standard to correct for disc thickness. The factor '1.33' denoted the value of the ratio of $\mathrm{A}_{1655} / \mathrm{A}_{3450}$ for fully $\mathrm{N}$-acetylated chitosan.

In the acid-base titration method (Domard and Rinaudo 1983), $0.1 \mathrm{~g}$ of chitosan was dissolved in 30 $\mathrm{mL}$ of $0.1 \mathrm{M} \mathrm{HCl}$. and titrated with $0.1 \mathrm{M} \mathrm{NaOH}$ solution using methyl orange as the indicator. The DD was calculated by the formula:

$$
\mathrm{DD}(\%)=\frac{\mathrm{C}_{1} \mathrm{~V}_{1}-\mathrm{C}_{2} \mathrm{~V}_{2}}{\mathrm{~m} \times 0.0994} \times 0.016
$$

where, $\mathrm{C}_{1}=$ concentration of standard $\mathrm{HCl}$ aqueous solution $(\mathrm{mol} / \mathrm{L}) ; \mathrm{C}_{2}=$ standard $\mathrm{NaOH}$ solution $(\mathrm{mol} / \mathrm{L}) ; \mathrm{V}_{1}=$ volume of the standard $\mathrm{HCl}$ aqueous solution used to dissolve chitosan $(\mathrm{mL}) ; \mathrm{V}_{2}=$ volume of standard $\mathrm{NaOH}$ solution consumed during titration $(\mathrm{mL}) ; \mathrm{m}=$ weight of chitosan $(\mathrm{g})$. The number $0.016(\mathrm{~g})$ is the equivalent weight of $\mathrm{NH}_{2}$ group in $1 \mathrm{~mL}$ of standard $1 \mathrm{M} \mathrm{HCl}$ aqueous solution and 0.0994 is the proportion of $\mathrm{NH}_{2}$ group by weight in chitosan.

All experiments were carried out in triplicate. All the data were checked for normality by Kolmogorov-Smirnov test. Since data were normally distributed, they were statistically analysed by one-way ANOVA followed by Tukey's studentized range tests at $\alpha=0.05$ by using the SPSS 16.0 for Windows software. 


\section{R.G. Sanuja et al.}

\section{RESULTS}

The highest percentage yields of chitosan were obtained from three crab shell samples Portunus pelagicus (Pp), Portunus sanguinolentus (Ps) and Scylla serrata (Ss), which yielded $34.13 \pm 3.72 \%$, $32.30 \pm 0.32 \%, 32.20 \pm 0.58 \%$ respectively. However, these values were not significantly different $(\mathrm{p}>0.05)$. The lowest yields were obtained from the two lobster shell samples, Panulirus homarus $(\mathrm{Ph})$ and Panulirus versicolor $(\mathrm{Pv})$, which yielded $15.73 \pm 1.22 \%$ and $14.53 \pm 0.47 \%$ respectively. These were also not significantly different from each other, but were significantly different from those of crab and shrimp shells $(\mathrm{p}<0.05)$. The yield of chitosan from $P$. monodon (Pm) shells, which was $24.27 \pm 2.81 \%$, was significantly different from that of crab and lobster shells (Table 1).

Table 1 Mean $( \pm S D)$ percentage yield of chitosan from crustacean shells. $n=6$, Means with different superscripts for each component are significantly different $(\mathrm{P}<0.05)$.

\begin{tabular}{ll}
\hline Crustacean shell type & $\begin{array}{l}\text { Yield } \\
(\%) \pm \mathrm{SD}\end{array}$ \\
\hline $\mathrm{Pm}$ (Penaeus monodon) & $24.27 \pm 2.81^{\mathrm{b}}$ \\
$\mathrm{Pp}$ (Portunus pelagicus) & $34.13 \pm 3.72^{\mathrm{c}}$ \\
$\mathrm{Ps}$ (Portunus sanguinolentus) & $32.30 \pm 0.32^{\mathrm{c}}$ \\
$\mathrm{Ss}$ (Scylla serrata) & $32.20 \pm 0.58^{\mathrm{c}}$ \\
$\mathrm{Ph}$ (Panulirus homarus) & $15.73 \pm 1.22^{\mathrm{a}}$ \\
$\mathrm{Pv}$ (Panulirus versicolor) & $14.53 \pm 0.47^{\mathrm{a}}$ \\
\hline
\end{tabular}

The percentage moisture contents of chitosan samples of $\mathrm{Pp}, \mathrm{Ps}, \mathrm{Ss}, \mathrm{Ph}$ and $\mathrm{Pv}$ were not significantly different $(\mathrm{p}>0.05)$ from each other, while that of Pm, which was the highest $(7.52 \pm 1.11 \%)$, was significantly different from other values (Table 2).

The highest percentage of ash was recorded in chitosan sample of Ss $(53.52 \pm 5.65 \%)$ which was significantly different $(\mathrm{p}<0.05)$ from that of other species (Table 2). The lowest percentage ash content was recorded in $\mathrm{Pm}(0.65 \pm 0.23 \%)$ and that too was significantly different from that of other species. There was no significant difference between the percentage ash content of $\mathrm{Pp}$ and $\mathrm{Ps}$ and also between $\mathrm{Ph}$ and $\mathrm{Pv}$ (Table 2).

The highest percentage of $\mathrm{N}$ was recorded in $\mathrm{Pm}$ and $\mathrm{Pv}(6.16 \pm 0.05 \%$ and $6.16 \pm 0.10 \%$ respectively); these were not significance different from each other
( $>>0.05)$. The lowest $\%$ of $\mathrm{N}$ was obtained for $\mathrm{Ss}$ $(2.02 \pm 0.03 \%)$. It was significantly different $(\mathrm{p}<0.05)$ from the chitosan samples of other species (Table 2).

The highest solubility was observed for the chitosan samples of Ss (47.91 $\pm 5.15 \%)$. However, it was not significantly different $(\mathrm{p}>0.05)$ from those of $\mathrm{Pp}$ and $P$ s $(44.31 \pm 2.11 \%$ and $35.63 \pm 4.28 \%$ respectively). There was no significant difference $(\mathrm{p}>0.05)$ between two lobsters $\mathrm{Ph}$ and $\mathrm{Pv}(22.46 \pm 3.18 \%$ and $17.57 \pm 1.32 \%$ respectively). The lowest solubility was observed for chitosan obtained from Pm $(15.28 \pm 0.62 \%)$ (Table 2).

The highest WBC was obtained for chitosan of Pm (600.61 $\pm 58.11 \%)$, which was significantly different $(p<0.05)$ from the rest. The lowest WBC values were obtained for chitosan of $\mathrm{Pp}$ and $\mathrm{Ss}$, which were $262.94 \pm 20.88 \%$ and $260.51 \pm 33.36 \%$ respectively; these were not significantly different ( $>0.05)$ from each other. Significant differences among chitosan of $\mathrm{Ps}, \mathrm{Ph}$ and $\mathrm{Pv}$ were also not observed ( $>0.05)$ (Table 2).

The maximum percentage of coconut oil binding capacity was observed in the chitosan of Pm $(644.15 \pm 18.63 \%)$, which was significantly different $(p<0.05)$ from the rest. The lowest value was recorded for chitosan of Ss $(298.38 \pm 9.87 \%)$, which was not significantly different $(\mathrm{p}>0.05)$ from that of $\mathrm{Pp}$ $(310.43 \pm 15.90)$. There was no significant difference among chitosan of $\mathrm{Ps}, \mathrm{Ph}$ and $\mathrm{Pv}$, which were $408.54 \pm 30.13 \%, 397.20 \pm 13.60 \%$ and $418.82 \pm 20.04 \%$ respectively (Table 2).

The maximum percentage of sunflower oil binding capacity was observed in the chitosan of Pm $(556.53 \pm 27.48 \%)$, which was significantly different $(\mathrm{p}<0.05)$ from the rest. The lowest value was obtained for chitosan of Pp (269.78 $\pm 4.69 \%)$, which was not significantly different ( $p>0.05)$ from that of Pp and Ss. There was no significant difference among the chitosan of $\mathrm{Ps}, \mathrm{Ph}$ and $\mathrm{Pv}$, where the values were $408.54 \pm 30.13 \%, 397.20 \pm 13.60 \%$ and $418.82 \pm 20.04 \%$ respectively (Table 2 ).

The maximum percentage of soybean oil binding capacity was exhibited in the chitosan of Pm $(565.21 \pm 11.89 \%)$, which was significantly different $(\mathrm{p}<0.05)$ from the rest. The lowest value was observed in Pp (306.74 $\pm 22.59 \%)$, which was not significantly different from that of Ps and Ss ( $p>0.05)$. There was no significant difference among the chitosan of $\mathrm{Ps}, \mathrm{Ph}$ and Pv (Table 2). 


\section{R.G. Sanuja et al.}

Table 2 Physicochemical and functional properties of chitosan isolated by different crustacean exoskeleton waste (dry weight basis). $\mathrm{n}=3$; Means with different superscripts in each row for each component are (a, b, c, d) significantly different $(\mathrm{P}<0.05)$; Abbreviations of species names are as given in Table 1.

\begin{tabular}{lllllll}
\hline Property & \multicolumn{7}{c}{ Chitosan samples } \\
\cline { 2 - 7 } & \multicolumn{1}{c}{ Pm } & \multicolumn{1}{c}{ Pp } & \multicolumn{1}{c}{ Ps } & \multicolumn{1}{c}{ Ss } & \multicolumn{1}{c}{ Ph } & \multicolumn{1}{c}{ Pv } \\
\hline Moisture \% & $7.52 \pm 1.11^{\mathrm{b}}$ & $3.58 \pm 1.15^{\mathrm{a}}$ & $3.98 \pm 0.77^{\mathrm{a}}$ & $3.25 \pm 0.81^{\mathrm{a}}$ & $3.69 \pm 0.90^{\mathrm{a}}$ & $3.16 \pm 1.77^{\mathrm{a}}$ \\
Ash \% & $0.65 \pm 0.23^{\mathrm{a}}$ & $30.02 \pm 4.21^{\mathrm{c}}$ & $27.48 \pm 1.12^{\mathrm{c}}$ & $53.52 \pm 5.65^{\mathrm{d}}$ & $16.36 \pm 0.47^{\mathrm{b}}$ & $11.56 \pm 1.00^{\mathrm{b}}$ \\
Nitrogen \% & $6.16 \pm 0.05^{\mathrm{d}}$ & $3.06 \pm 0.10^{\mathrm{b}}$ & $4.44 \pm 0.41^{\mathrm{c}}$ & $2.02 \pm 0.03^{\mathrm{a}}$ & $4.66 \pm 0.12^{\mathrm{c}}$ & $6.16 \pm 0.10^{\mathrm{d}}$ \\
Solubility \% & $15.28 \pm 0.62^{\mathrm{a}}$ & $44.31 \pm 2.11^{\mathrm{d}}$ & $35.63 \pm 4.28^{\mathrm{bc}}$ & $47.91 \pm 5.15^{\mathrm{cd}}$ & $22.46 \pm 3.18^{\mathrm{ab}}$ & $17.57 \pm 1.32^{\mathrm{ab}}$ \\
WBC\% & $600.61 \pm 58.11^{\mathrm{c}}$ & $262.94 \pm 20.88^{\mathrm{a}}$ & $369.57 \pm 21.76^{\mathrm{b}}$ & $260.51 \pm 33.36^{\mathrm{a}}$ & $417.51 \pm 27.93^{\mathrm{b}}$ & $462.92 \pm 3.06^{\mathrm{b}}$ \\
FBC \% & & & & & & \\
Coconut oil & $644.15 \pm 18.63^{\mathrm{c}}$ & $310.43 \pm 15.90^{\mathrm{a}}$ & $408.54 \pm 30.13^{\mathrm{b}}$ & $298.38 \pm 9.87^{\mathrm{a}}$ & $397.20 \pm 13.60^{\mathrm{b}}$ & $418.82 \pm 20.04^{\mathrm{b}}$ \\
Sunflower oil & $556.53 \pm 27.48^{\mathrm{c}}$ & $269.78 \pm 4.69^{\mathrm{a}}$ & $357.31 \pm 21.95^{\mathrm{b}}$ & $276.10 \pm 7.91^{\mathrm{a}}$ & $372.93 \pm 25.52^{\mathrm{b}}$ & $397.25 \pm 18.48^{\mathrm{b}}$ \\
Soybean oil & $565.21 \pm 11.89^{\mathrm{c}}$ & $306.74 \pm 22.59^{\mathrm{a}}$ & $356.12 \pm 19.08^{\mathrm{ab}}$ & $313.39 \pm 11.21^{\mathrm{a}}$ & $378.59 \pm 9.51^{\mathrm{b}}$ & $389.31 \pm 34.40^{\mathrm{b}}$ \\
\hline
\end{tabular}

The FT-IR spectra for chitosan isolated from the shells of different crustacean species are shown in Figure 1. A major functional group presents in chitosan is the free amino group $\left(-\mathrm{NH}_{2}\right)$ at $\mathrm{C} 2$ position of glucosamine. This absorption band was observed between the 1070 and $1075 \mathrm{~cm}^{-1}$ in all six chitosan samples (Table 3).

Table 3 The absorption band and absorbance units of free amino group $\left(-\mathrm{NH}_{2}\right)$ of chitosan samples. Species abbreviations are as given in Table 1.

\begin{tabular}{lll}
\hline $\begin{array}{l}\text { Chitosan } \\
\text { sample }\end{array}$ & $\begin{array}{l}\text { Absorption } \\
\text { band }\left(\mathrm{cm}^{-1}\right)\end{array}$ & $\begin{array}{l}\text { Absorbance } \\
\text { units }\end{array}$ \\
\hline $\mathrm{Pm}$ & 1073.79 & 0.91328 \\
$\mathrm{Pp}$ & 1072.26 & 0.28284 \\
$\mathrm{Ps}$ & 1073.71 & 0.45856 \\
$\mathrm{Ss}$ & 1070.25 & 0.70827 \\
$\mathrm{Ph}$ & 1072.73 & 0.66957 \\
$\mathrm{Pv}$ & 1072.73 & 0.66957 \\
\hline
\end{tabular}

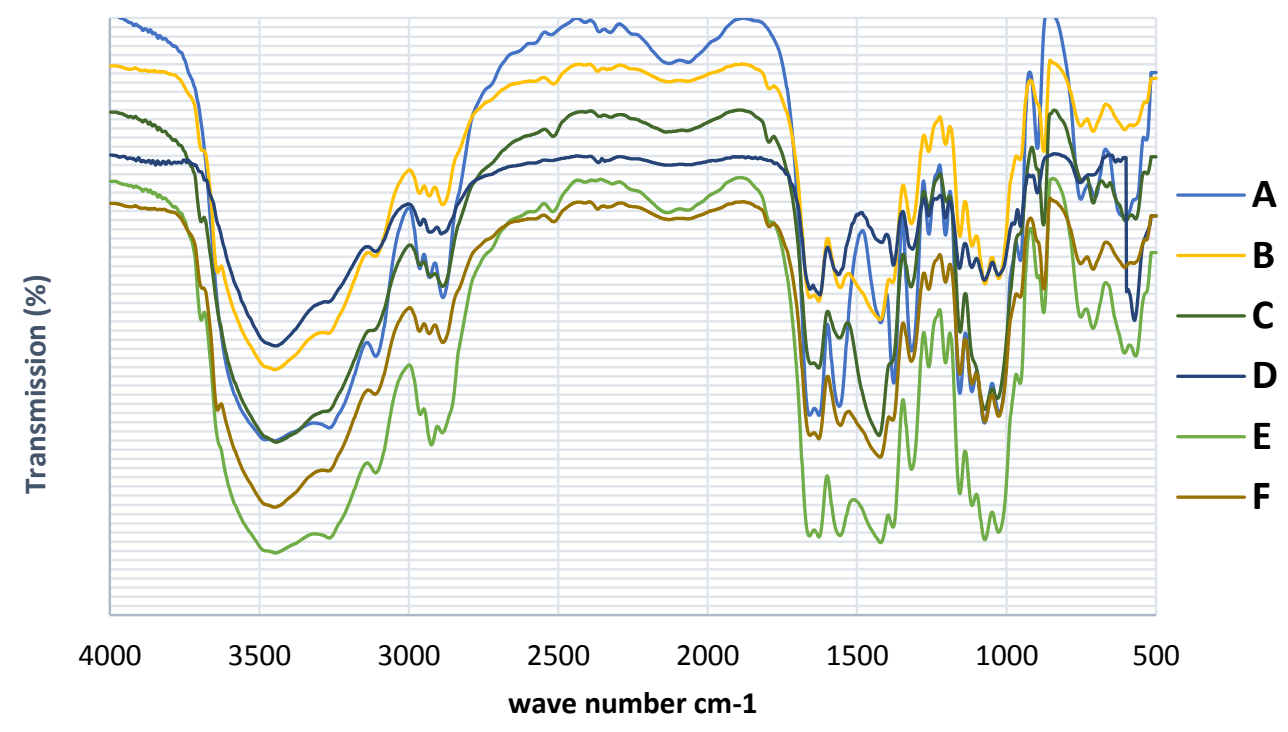

Fig. 1 A-The FT-IR spectra of chitosan samples from (A) P. monodon (B) P. pelagicus (C) S. serrata (D) $P$. homarus (E) P. versicolor (F) P. sanguinolentus

Sri Lanka J. Aquat. Sci. 22(1) (2017): 45-53 
The highest absorbance value was obtained chitosan of Penaeus monodon (0.91328 units), indicating that it has the highest amount of free amino groups at $\mathrm{C} 2$ position of glucosamine. The lowest value was exhibited by the chitosan of Portunus pelagicus (Table 3). The values for DD for chitosan of different species obtained using FT-IR spectroscopy and the acid base titration are given in Table 4 .

The absorbance at $1655 \mathrm{~cm}^{-1}$ of the amide-I band as a measure of the $\mathrm{N}$-acetyl group content and $3450 \mathrm{~cm}^{-1}$ of the $-\mathrm{OH}$ stretching was obtained from the FT-IR spectra. The highest percentage of DD (40.99\%) was observed in the chitosan of Pm (Table 4).

The results of percentage values of DD obtained from the acid-base titration was quite similar to those obtained from FT-IR spectroscopy (Table 4). The highest percentage of DD using acid-base titration was also found for chitosan of Pm $(40.51 \pm 0.09 \%)$. However, this value was not significantly different ( $p>0.05$ ) from those of $\mathrm{Pp}, \mathrm{Ph}$ and $\mathrm{Pv}$ (Table 4).

Table 4 Mean degree of de-acetylation percentage of chitosan samples from Khan et al. (2002) equation and acid-base titration. Species abbreviations are as given in Table 1. Means with different superscripts for each component are significantly different $(\mathrm{P}<0.05)$.

\begin{tabular}{lll}
\hline $\begin{array}{l}\text { Chitosan } \\
\text { sample }\end{array}$ & $\begin{array}{l}\text { DD \% of } \\
\text { chitosan } \\
\text { from } \\
\text { equation }\end{array}$ & $\begin{array}{l}\mathrm{DD} \% \pm \mathrm{SD} \text { of } \\
\text { chitosan from } \\
\text { titration }\end{array}$ \\
\hline $\mathrm{Pm}$ & 40.9892 & $40.51 \pm 0.09^{\mathrm{b}}$ \\
$\mathrm{Pp}$ & 38.8434 & $34.85 \pm 1.55^{\mathrm{ab}}$ \\
$\mathrm{Ps}$ & 31.2927 & $33.70 \pm 3.22^{\mathrm{a}}$ \\
$\mathrm{Ss}$ & 36.9098 & $32.63 \pm 2.68^{\mathrm{a}}$ \\
$\mathrm{Ph}$ & 33.3858 & $35.76 \pm 3.34^{\mathrm{ab}}$ \\
$\mathrm{Pv}$ & 35.3959 & $33.60 \pm 5.39^{\mathrm{ab}}$ \\
\hline
\end{tabular}

\section{DISCUSSION}

Yield of chitosan extracted in this study from crustacean waste varied from $14.53 \pm 0.47 \%$ to $34.13 \pm 3.72 \%$ (Table 1). The low yields were obtained from lobster shells, while the crabs having high yield. The yield of chitosan from the Penaeus monodon waste was $24.27 \pm 2.81 \%$, which was more or less similar to the yield of $23 \%$ reported by No and Meyers (1992). Relatively low chitosan yield from this study could be due to de-polymerization, excessive removal of acetyl groups from the polymer during de-acetylation and loss of chitosan particles during washing.

FT-IR studies showed that free amino group content is high in the extracted chitosan samples. The highest absorbance was recorded for P. monodon (Table 4), which was similar to the value reported by Puvvada et al. (2012).

The moisture content of chitosan samples extracted in this study was ranged from $3.16 \pm 1.77 \%$ to $7.52 \pm 1.11 \%$ (Table 2), P. monodon sample recording the highest value. Commercial chitosan products contain less than $10 \%$ moisture ( $\mathrm{Li}$ et al. 1992). Chitosan is hygroscopic in nature (Khan et al. 2002) hence it can absorb moisture during storage.

Ash content is an indicator of the effectiveness of the de-mineralization step for removal of $\mathrm{CaCO}_{3}$. De-mineralization usually results in products having $31-36 \%$ of ash (Tsai and Hwang 2004). The fresh shrimp shells have $32.27 \%$ of ash (Hossain and Iqbal 2014). A high quality grade chitosan should have less than $1 \%$ of ash (Hossain and Iqbal 2014). However, in the present study, only chitosan of Penaeus monodon has an ash content less than $1 \%$. In others, it was as high as $11.56-52.52 \%$. Some residual ash of chitosan may affect their solubility consequently contributing to lower viscosity or can affect other more important characteristics of the final product such as $\mathrm{N}$-content (No and Meyers 1995).

The $\mathrm{N}$-content in chitosan samples of all species used in the present study was lower than that was reported by No and Meyers (1995) for crab and shrimp shells. Percentage nitrogen content can be increased due to the presence of protein residues (Rutherford and Austin 1978). Protein is bound by covalent bonds forming stable complex with chitosan. Thus, it is very difficult to achieve $100 \%$ deproteinization. Even with complete de-proteinization, nitrogen of the free amino $\left(-\mathrm{NH}_{2}\right)$ group cannot be estimated (Nessa et al. 2010). The pre-conditioning step might be helpful to reduce the protein content of the shells at the beginning of the isolation of chitosan.

Lower solubility values suggest incomplete removal of protein and acetyl group (Brine and Austin 1981; Islam et al. 1981) since solubility of chitosan depends on the removal of acetyl group from chitin. Therefore, the lower DD value and the presence of protein contaminants in the sample during the process of analysis could adversely interfere with the results (Nessa et al. 2010). According to Nessa et al. (2010), very good quality chitosan has high value of solubility due to higher DD. The solubility of chitosan extracted 
in the present study varied from $15.28 \pm 0.62 \%$ to $47.91 \pm 5.15 \%$.

Although chitosan is insoluble in water, it has the ability to bind with water. This quality is important to various applications of chitosan. Chitosan sample of $P$. monodon showed the highest percentage of WBC (Table 2), which is similar to those reported by Cho et al. (1998). The other samples showed lower WBC probably due to low DD.

In the present study, coconut oil binding capacity of chitosan was evaluated because Sri Lankans use high amounts of coconut oil for the cooking purposes. The highest FBC\% was recorded for chitosan of P. monodon (644.15\%, 556.53\% and $565.21 \%$ regard to coconut oil, sunflower oil and soybean oil respectively), were similar to the values reported by No et al. (2000). Merzendorfer (2006) reported that changing the sequence of isolation steps as demineralization, de-proteinization and de-acetylation results in an increase in FBC than when deproteinization is done prior to demineralization.

DD of chitosan is a quality parameter that indicates the percentage of the acetyl group. Higher degree of deacetylation indicates better conversion of chitin to chitosan (Zhou et al. 2007). Medical and pharmaceutical applications of chitosan as antitumor, hemostatic, hypocholesterolemic, antimicrobial, and antioxidant depends mostly on its DD and solubility (Muzzarelli and Muzzarelli 2005). In the present study, the highest DD\% value was recorded for chitosan of $P$. monodon. DD values are not only highly dependent on the source and method of purification (No et al. 1989) but also on the type of analytical methods employed, sample preparation, and type of instrument used (Khan et al. 2002).

Results of the present study showed that the most suitable crustacean exoskeleton waste from fish processing industry to isolate chitosan is Penaeus monodon waste from which high quality chitosan can be extracted.

\section{Acknowledgements}

Authors are thankful to Department of Fisheries and Aquaculture and Department of Chemistry of the University of Ruhuna, Sri Lanka for providing necessary laboratory and library facilities. Special thanks goes to the Department of Materials Science and Engineering of the University of Moratuwa, Sri Lanka for providing facilities for Fourier Transformed InfraRed spectroscopy and to the National Aquatic
Resources Research and Development Agency, Crow Island, Colombo 15, Sri Lanka, for providing laboratory facilities for the nitrogen analysis.

\section{REFERENCES}

AOAC 1995. Official Methods of Analysis of the Association of Official Analytical Chemists. Volume 1 and 2, 16th edition. AOAC International, Arlington, Virginia.

Badawy M.E.I. and E.I. Rabea 2011. A biopolymer chitosan and its derivatives as promising antimicrobial agents against plant pathogens and their applications in crop protection. International Journal of Carbohydrate Chemistry, 2011: 1-29. doi: 10.1155/2011/460381

Brine C.J. and P.R. Austin 1981. Chitin variability with species and method of preparation. Comparative Biochemistry and Physiology 69B: 283-286.

doi: 10.1016/0305-0491(81)90242-X

Cheba B.A. 2011. Chitin and chitosan: marine biopolymers with unique properties and versatile applications. Global Journal of Biotechnology \&. Biochemistry 6(3): 149-153.

Cho Y. I., H.K. No and S.P. Meyers 1998. Physicochemical Characteristics and Functional Properties of various Commercial Chitin and Chitosan Products. Journal of Agricultural and Food Chemistry 46(9): 38393843.

Domard A. and M. Rinaudo 1983. Preparation and characterization of fully deacetylated chitosan. International Journal of Biological Macromolecules 5: 49-52. doi: 10.1016/01418130(83)90078-8

Hossain M. and A. Iqbal 2014. Production and Characterization of Chitosan from Shrimp Waste. Journal of Bangladesh Agriculture University 12(1): 153-160.

Huang M., E. Khor ad L.Y. Lim 2004. Uptake and cytotoxicity of chitosan molecules and nanoparticles: Effects of molecular weight and degree of deacetylation. Pharmaceutical Research 21 (2): 344-353.doi: 10.1023/B:PHAM.0000016249.52831.a5

Islam M.M., S.M. Masum, M.M. Rahman, M.A.I. Molla, A.A. Shaikh, S.K. Roy 2011. Preparation of chitosan from shrimp shell and investigation of its properties. International 


\section{R.G. Sanuja et al.}

Journal of Basic and Applied Sciences 11(1): 77-80.

Jayakody D.S. 1997. The Spiny Lobster Fishery in Relation to Bottom Conditions on the South Coast of Sri Lanka. Journal of National Aquatic Resources and Research Agency 35: 1-10.

Kassai M.A. 2008. Review of several reported procedures to determine the degree of $N$ acetylation for chitin and chitosan using infrared spectroscopy. Carbohydrate Polymers 71: 497-508.

doi: 10.1016/j.carbpol.2007.07.009

Khan T., K. Peh and H.S. Chang 2002. Reporting degree of de-acetylation values of chitosan: The influence of analytical methods. Journal of Pharmacology and Pharmaceutical Science 5(3): 205-212.

Knorr D. 1982. Functional properties of chitin and chitosan. Journal of Food Science 47: 593-595. doi: 10.1111/j.1365-2621.1982.tb10131.x

Knorr D. 1991. Recovery and utilization of chitin and chitosan in food processing waste management. Food Technology 1991: 114122.

Krishnaveni B. and R. Ragunathan 2015. Extraction and characterization of Chitin and Chitosan from Aspergillus terreus sps, synthesis of their bionanocomposites and study of their productive applications. Journal of Chemical and Pharmaceutical Research 7(2): 115-132. doi: $10.1007 / \mathrm{s} 12010-016-2286-2$

Kumar M.N.R. 2000. A review of chitin and chitosan applications. Reactive and Functional Polymers 46: 1-27. doi: 10.1016/S13815148(00)00038-9

Li Q., E.T. Dunn, E.W. Grandmaison and M.F.A. Goosen 1992. Applications and properties of chitosan. Journal of Bioactive and Compatible Polymers 7: 370-397. doi: $10.1177 / 088391159200700406$

Liyanage U.S.P.K. and B. Long 2009. Status of the south coast spiny lobster fishery. CENARA project report. National Aquatic Resources Research and Development Agency, Sri Lanka. pp 6-45.

Merzendorfer H. 2006. Insect chitin synthases: a review. Journal of Comparative Physiology 176: 1-15. doi: 10.1007/s00360-005-0005-3

Muzzarelli R.A.A. and G.W. Gooday 1986. Chitin in Nature and Technology. Plenum Publishing Corporation, New York.
Muzzarelli R.A.A. and R. Rochetti 1985. Determination of the degree of deacetylation of chitosan by first derivative ultraviolet spectrophotometry. Journal of Carbohydrate Polymer 5: 461-72.

Muzzarelli R.A.A. and C. Muzzarelli 2005. Chitosan chemistry: Relevance to the biomedical sciences. Advanced Polymer Science 186: 151209. doi: $10.1007 / \mathrm{b} 136820$

Nessa F., S.M. Masum, M. Asaduzzaman, S.K. Roy, M.M. Hossain and M.S. Jahan 2010. A process for the preparation of chitin and chitosan from prawn shell waste. Bangladesh Journal of Scientific and Industrial Research 45(4): 323330. doi: 10.3329/bjsir.v45i4.7330

No H.K., S.P. Meyers and K.S. Lee 1989. Isolation and characterization of chitin from crawfish shell waste. Journal of Agricultural and Food and chemistry 37(3): 575-579. doi: 10.1021/jf00087a001

No H.K. and S.P. Meyers 1995. Preparation and characterization of chitin and chitosan: A review. Journal of Aquatic Food Production Technology 4(2): 27-52. doi: 10.1300/J030v04n02_03

No H.K. and S.P. Meyers 1992. Utilization of crawfish processing wastes as carotenoids, chitin, and chitosan sources. Journal of Korean Society Food Nutrition 21: 319-326.

No H.K., K.S. Lee and S.P. Meyers 2000. Correlation between physicochemical characteristics and binding capacities of chitosan products. Journal of Food Science 65(7): 1134-1137. doi: 10.1111/j.1365-2621.2000.tb10252.x

Puvvada Y.S., S. Vankayalapati and S. Sukhavasi 2012. Extraction of chitin from chitosan from exoskeleton of shrimp for application in the pharmaceutical industry. International Current Pharmeceutical Journal 1(9): 258-263. doi: 10.3329/icpj.v1i9.11616

Ravi Kumar M.N.V. 2000. A review of chitin and chitosan applications. Reactive and Functional Polymers 46(1): 1-27. doi: 10.1016/S13815148(00)00038-9

Rutherford F.A. and P.R. Austin 1978. Marine chitin properties and solvents. pp. 182-192. In: Muzzarrelli R.A.A. and P.R. Austin (eds), Proceedings of the First International Conference on Chitin /Chitosan. MIT Sea Grant Program, Cambridge, MA.

Sri Lanka J. Aquat. Sci. 22(1) (2017): 45-53 
Sewvandi G.A. and S.U. Adikary 2012. Synthesizing and characterization of natural biopolymer chitosan derived from shrimp type, Penaeus monodon. Tropical Agricultural Research 23(3): 272-276. doi: 10.4038/tar.v23i3.4664

Thibaut V.J.C., N. Anne, L.L. Joseph, B. Richard, J.S. Margaret and R. Thomas 2016. Preparation of magnetic carboxymethylchitosan nanoparticles for adsorption of heavy metal ions. ACS Omega 1(1): 77-83. doi: 10.1021/acsomega.6b00035

Toan N.V. 2009. Production of chitin and chitosan from partially autolysis shrimp shell materials. The Open Biomaterials Journal 1: 21-24.

doi: 10.2174/1876502500901010021

Tsai G.-J. and S.-P. Hwang 2004. In Vitro and In Vivo antibacterial activity of shrimp chitosan against some intestinal bacteria. Fisheries Science 70: 675-681.

doi: 10.1111/j.1444-2906.2004.00856.x

Trung T.S., W.W. Thein-Han, N.T. Qui, C.H. Ng and W.F. Stevens 2006. Functional characteristics of shrimp chitosan and its membranes as affected by the degree of deacetylation. Bioresource Technology 97(4): 659-663.

doi: 10.1016/j.biortech.2005.03.023

Wan Ngah W.S., N.F.M. Ariff, A. Hashim and M.A.K.M. Hanafiah 2010. Malachite green adsorption onto chitosan coated bentonite beads: Isotherms, kinetics and mechanism. Clean: Soil, Air, Water 38: 394-400.

doi: 10.1002/clen.200900251

Wang S.L., T.J. Chang and T.W. Liang 2010. Conversion and degradation of shellfish wastes by Serrata sp. fermentation for the production of enzymes and bioactive materials. Biodegradation 21: 321-333. doi: 10.1007/s10532-009-9303-x

Zhou H.Y., X.G. Chen, M. Kong, C.S. Liu, D.S. Cha and J.F. Kennedy 2007. Effect of molecular weight and degree of chitosan de-acetylation on the preparation and characteristics of chitosan thermo sensitive hydrogel as a delivery system. Carbohydrate Polymer 73: 265-273. doi: 10.1016/j.carbpol.2007.11.026 